\title{
Impact of lockdown on the mining industry in India
}

\author{
Pradeep Kumar Jain ${ }^{1}$
}

Published online: 20 April 2021

(C) The Author(s), under exclusive licence to Springer-Verlag GmbH Germany, part of Springer Nature 2021

\begin{abstract}
Mining is an essential industry that will provide key materials needed for India infrastructure development. Mining is one of the core sectors and growth driver of Indian economy. Minerals and ores provide basic raw materials to many important industries like power generation (thermal), iron and steel, cement, petroleum and natural gas, petrochemicals, fertilizers, precious and semiprecious metals/stones for jewellery, electrical and electronics equipment, glass, ceramics, etc. The mining sector in India was poised for robust growth in financial year 2020-2021, on the back of rising demand from end-use sectors and fresh investments announced by the mining companies. However, the spread of COVID-19, right at the beginning of the financial year, has led to disruptions across industries. There is a significant scope for new mining capacities in iron ore, bauxite, coal and other minerals and considerable opportunities for future discoveries of sub-surface deposits. Infrastructure projects continue to provide lucrative business opportunities for steel, zinc and aluminium producers. Iron and steel make up a core component for the real estate sector. Demand for these metals is set to continue given strong growth expectations for the residential and commercial building industry. India's mining sector expected to show positive growth in 2021 compared to 2020. As different arms of the government work with stakeholders to bring the economy on the growth path, it is important for the policymakers of mining to continue making such changes to the policies, which can ramp up the contribution of the sector to GDP. In the present paper, an overview of impact of lockdown on the mining industry in India is discussed with special reference to production scenario of minerals, employment, export-import scenario of ores and minerals and other developments during the period.
\end{abstract}

Keywords Mining · COVID-19 · Lockdown · Industry · Gross value added · Employment · Auction · Mining plan · Essential services

\section{Introduction}

Mining is an essential industry that will provide key materials needed for the country's infrastructure development. Mining is one of the core sectors and growth driver of Indian economy. Minerals and ores provide basic raw materials to many important industries like power generation (thermal), iron and steel, cement, petroleum and natural gas, petrochemicals, fertilizers, precious and semi-precious metals/stones, electrical and electronics equipment, glass and ceramics. The rapid spread of COVID-19 has disrupted operations across industries, and mining sector is no exception. Ministry of Home Affairs, Govt. of India order dated 24 March 2020 issued guidelines for containment of COVID-19 pandemic in the

Pradeep Kumar Jain

pkjain3661@gmail.com

1 Indian Bureau of Mines, Nagpur, India country, whereby barring few industries, it was declared that industrial establishments will be closed. However, vide another order date 24 March 2020, the restrictions of lockdown were excluded inter alia with respect of operations of mines of iron ore, cocking coal, thermal coal, limestone, dolomite, manganese ore, chromite, etc. as well as operation of ferroalloy, iron ore pellet plants, etc. The mining sector in India was poised for robust growth in financial year 2020 2021 , on the back of rising demand from end-use sectors and fresh investments announced by the mining companies. However, the spread of COVID-19, right at the beginning of the financial year, has led to disruptions across industries.

In the initial period of lockdown, the COVID-19 pandemic has adversely affected the mining of ferrous, non-ferrous and minor minerals. To continue, the operations of mines which supply raw material to steel plants like iron ore, coking coal, thermal coal, limestone, dolomite, manganese and chromite and running of ferro alloy and pellet plants covered under "essential services" were exempted from the nationwide lockdown. However, the mine owners and operators were facing 
difficult to continue the mining activities. This is due to business disruptions and operational difficulties (non-availability of requisite workforce, restriction on free movement of men and material, high risk of spread of pandemic, disruption of port operation), exacerbated by fall in demand from downstream industries and manufacturers of white goods. Stopping production and shutting down smelters, blast furnace and other plants are costly affairs and generally not viable options.

In light of the current COVID-19 pandemic, the mine owners and operators have faced lots of challenge. Both state and central government revenue collections against statutory levies and taxes are expected to get affected collection due to lower volume of mineral production during COVID-19 crisis. This is due to lower mineral offtake on account of lack of demand from end-user sectors and also non-availability of labour. The COVID-19 led disruption to the global trade as well, and subdued global markets are also likely to impact the demand and production of minerals. The demand disruption of minerals is likely to have a profound impact on the employment and well-being of the local communities. They need to relook their existing subcontracts of various mining operation, off take agreements, advance purchase and sale agreement and other related contracts. They also need to factor whether any event of default, force majeure, frustration, change in law and material adverse change has triggered any of the agreements. The mining industry has paid various types of taxes in the form of direct taxes and indirect taxes and mining levies. These taxes and levies are a big source of revenue for the Government. During the period of initial lockdown, government revenues from mining were badly affected. COVID-19 has given the country a reason for fundamentally questioning and reforming our way of doing business. The government has started moving in this direction with initiatives like preembedded clearances.

The contribution of quarrying and mining sector to gross value added (GVA) (at current prices) of country was Rupees 1238.04 billion during the year 2020-2021 H1 (AprilSeptember) as compared to Rupees 1807.71 billion during the same period in year 2019-2020 H1 (April-September). As per available information, the contribution of mining and quarrying to all India gross value added (GVA) is $1.58 \%$ during the year 2020-2021 H1 (April-September) as compared to $2.02 \%$ reduced to about $32 \%$ in year $2019-2020$ H1. Contribution of mining and quarrying sector in all India GVA during 2019-2020 and 2020-2021 H1 (AprilSeptember) is given in the Annexure I.

\section{Production scenario of MCDR minerals}

During the period from April to September in FY 2020-2021, almost all the minerals show the downfall of production as compared to the corresponding period of last FY 2019-2020 except garnet (17\%), kyanite (367\%), lead and zinc ore $(1 \%)$, lead concentrate $(5 \%)$, sillimanite $(28 \%)$ and zinc concentrate $(0.45 \%)$ due to state-specific lockdown relaxation for working in mines. Among the Mineral Conservation and Development Rules (MCDR) minerals, the major downfall reported during April to September in FY 2020-2021 in copper (35\%), chromite $(70 \%)$, diamond $(51 \%)$, fluorite (graded) $(72 \%)$, gold ore $(37 \%)$, iolite $(77 \%)$, iron ore $(33 \%)$, magnesite $(42 \%)$, manganese ore $(38 \%)$, selenite $(76 \%)$, silver $(60 \%)$, tin concentrate $(54 \%)$, vermiculite $(81 \%)$, etc. No production of limeshell and rock salt is reported during FY 2020-2021 (April to September). As per available information, the production of MCDR minerals during year 2019-2020 (from April to September) and 2020-2021 (from April to September) and percentage change is given in Annexure II.

\section{Employment}

During the year 2020-2021 (April to September), the provisional average daily labour employment is increased in the mines of bauxite, Fluorite and tin due to local mine specific requirement, however overall about $14 \%$ reduction in labour employment in the mines. There is no daily labour reported in the mines of Apatite and lime shell due to nil production. The mineral wise provisional number of mines and average daily labour employment during 2019-2020 (H1) and 2020-2021 (H1) is furnished in Annexure III.

\section{Export-import scenario of ores and minerals}

During the period from April to September in FY 2020-2021, the total value of export of ore and minerals is Rs. 70,177 crore, declined by $30.65 \%$ as compared to Rs. 101,191 during the same period of FY 2019-2020, while the value of import of ore and mineral is also declined to Rs. 298,296 crore by $48.62 \%$ as compared to Rs. 580,548 during the same period of FY 2019-2020. Export and import of ores and minerals during financial year 2019-2020 (up to Sep. 2019) and 2020 2021 (up to Sep. 2020) are given in Annexure IV.

The Government of India has taken several steps to help industries brave the aftermath of the pandemic. Statutory clearances/approvals have been extended to facilitate the mine owner during the lockdown. On 16 May 2020, the Finance Minister of India has, in continuation to the economic stimulus package in light of COVID-19, announced certain structural reforms like commercial coal mining, a composite exploration-mining-production, removal of distinction between captive and merchant mines, etc. in relation to coal and other minerals. The decision to permit commercial coal mining on revenue sharing basis where bidders for auction would be required to bid for a percentage share of revenue payable to the government, with easy entry and exit norm, is viewed as an attempt to attract and allow domestic as well as global players to help ramp up coal production in India. 
The Government has further announced that 500 blocks are proposed to be auctioned through an open and transparent auction process. The reforms initiated by the Government are aimed to impact the sectors which are considered new horizons of growth, with the aim to unleash new investment, boost production and create jobs. However, during these challenging times, the mine owners and operators take steps to carefully analyze and effectively navigate the legal challenges and propel the mining industry towards a new dawn.

\section{Important development during the period of lockdown in the mining sector}

Important activities/happenings in the Indian mining and mineral sector are described below, and few of them were planned earlier to COVID-19 as continuous mining reform processes:

1) Central Government has enacted the Mineral Laws (Amendment) Act, 2020, to amend Mines Minerals (Development and Regulation) Act, 1957, and Coal Mines (Special Provisions) Act, 2015, vide notification published in the Official Gazette dated 13 March 2020. The said Act will open a new era in Indian coal and mining sector especially to promote ease of doing business. In compliance of provision of said Act, the Minerals (Other than Atomic and Hydrocarbons Energy Minerals) Concession Rules, 2016, and Mineral (Auction) Rules, 2015, was amended vide notification no. General Statutory Rules (G.S.R.) 191(E) dated 20 March 2020 and General Statutory Rules (G.S.R.) 190(E) dated 20 March 2020, respectively.

2) The Govt directed to the State Govt. to nominate a secretary level officer who is the administrative head of the Ministry or Department of that State as the Nodal Officer in respect of leases expiring under Section 8A(5)(6) of the MMDR Act, 1957. The nodal officer shall be authorized to collect all the valid rights, approvals, clearances, licenses, etc. (Gazette Notification No. General Statutory Rules (GSR) 191(E) dated 20 March 2020, Ministry of Mines, Government of India).

3) Ministry of mines is in the process of formulation of a national non-ferrous metals (aluminium and copper) scrap recycling policy. Accordingly, a draft of the said policy has been prepared and is being circulated on 27 March 2020 for comments from stakeholders and the public at large. Recently, the Government has published National Non-Ferrous Metal Scrap Recycling Framework, 2020.

4) Extend all the valid clearances including environmental clearance vested with previous lessee for a period of 2 years from the commencement of new lease (Gazette
Notification No. SO 1224(E) dated 28 March 2020, Ministry of Environment, Forest and Climate Change, Government of India).

5) Hon'ble Finance Minister on 16 May 2020 has made announcement under Atmanirbhar Bharat scheme (an economic stimulus package to cater to various sections including mining sector) for enhancing private sector investments in mineral sector and for bringing reforms in mineral sector. In order to implement the announcement, legislative amendments to the Mines and Mineral (Development and Regulation) Act, 1957, and rules made there as well as other proposals are being considered by the Ministry of Mines.

6) Vide order no. 16/4/2020-MVI dated 03 June 2020, the Central Government, in exercise of the power conferred under Section 20A of the MMDR Act, 1957, in the national interest directs the state government to follow the guidelines for pre-embedded clearances annexed with this order and implement the same in letter and spirit.

7) Allow public sector unit Steel Authority of India Limited (SAIL) to sale fines and tailings from old ore stocks and also give permission to sell $25 \%$ of its last year production in open market. Recently, the Government has also granted permission to Neelachal Ispat Nigam Limited (NINL) to sell up to $25 \%$ of its annual iron ore production as per the MDPA executed by the company for a period of 1 year or till the completion of disinvestment of the company, whichever is earlier.

8) Out of the total 103 mineral blocks auctioned since 2015, so far out of which, a total of 27 mineral blocks has successfully been auctioned in year 2020 in the states of Madhya Pradesh (limestone-2, bauxite-1 and gold-2) and Odisha (iron-13, iron ore and manganese6, manganese-2 and chromite-1).

9) As per available information in Press Information Bureau's (PIB) press release on 31 March 2020, the Union Commerce and Industry Ministry announced changes in the Foreign Trade Policy (FTP) of the Government of India. The present Policy, which came into force on 1 April 2015, is for 5 years and has validity up to 31 March 2020. In view of the unprecedented current situation arising out of the pandemic novel coronavirus (COVID-19), the Govt. has decided to continue relief under various export promotion schemes by granting extension of the existing Foreign Trade Policy by another 1 year, i.e. up to 31 March 2021.

10) Ministry of Mines has directed IBM to identify the nonworking leases and issues related to their closure and make a plan to early start of them.

11) Indian Bureau of Mines (IBM) has approved all the mining plan received of auctioned leases which was expired 
in 2020 within a time frame of 30 days. IBM has further facilitated leases during the period of COVID-19 by facilitating early disposal of mining plans.

12) Technological solutions have been provided to industry for value addition and efficient utilization of low grade, sub-grades and complex ores and mineral industry and waste utilization of iron ore, bauxite, rock phosphate, manganese, etc. and for recovery of byproducts.

13) Efforts are being made to expedite clearances in respect of these auctioned mines to operationalize them at the earliest.

Consequent to national lockdown announced on 24 March 2020, the Central Government issued vide Ministry of Home Affairs order no. 40-3/2020 dated 24 March 2020 "Guidelines on the measures to be taken by Ministries/ Departments of Government of India, State/Union Territory Governments and State/Union Territory Authorities for containment of COVID-19 Epidemic in the Country". This document stated that industrial establishments will remain closed, except for manufacturing of essential commodities and specific production units with prior permissions. On the next day, an addendum was issued to exclude certain industries and "coal and mineral production, transportation, supply of explosives and activities incidental to mining operations" by Ministry of Home Affairs, Government of India.

In continuation to the above guidelines by the Central Government, the State Government of Odisha invoked the Epidemic Diseases Act of 1897 and issued Orissa COVID19 Regulations, 2020, under it. These regulations allow the government to exclude "essential services" from any lockdown restrictions. An order $(9015 / \mathrm{H} \& \mathrm{FW})$ issued by the Health and Family Welfare Department on March 24th has excluded the following from any restrictions, subject to preventive measures like social distancing and containment: "Operation of mines of iron ore, coking coal, thermal coal, limestone, dolomite, manganese, chromite etc. as well as operations of ferroalloys, iron ore pellet plants etc. which are supply critical raw material for steel making". In line with the above guidelines, the mining operations particularly in captive mines continued during the lockdown period.
Permission to the sale of $25 \%$ iron ore to SAIL: Considering shortage of iron ore due to expiry of mining leases on 31 March 2020 and due to non-working of auctioned iron ore mines, the Govt of India granted permission of selling minerals at $25 \%$ of the previous year production (quantity) of iron ore to M/s SAIL. State-wise sale figures and details are given below:

\section{Indian mining sector in 2021}

The country's mining sector is expected to see "hectic activities" in the new year with the central government's approvals for pending mining reforms expected in January itself and efforts continuing to bolster overall mineral output and will be a "bridge year between the past and the future". There is a significant scope for new mining capacities in iron ore, bauxite, coal and other minerals and considerable opportunities for future discoveries of sub-surface deposits. Infrastructure projects continue to provide lucrative business opportunities for steel, zinc and aluminium producers. Iron and steel make up a core component for the real estate sector. India mining sector expected to show positive growth in 2021 compared to 2020. IBM also made a plan to use space technology in monitoring of mines and also gives thrust for implementation of online system of mine plan processing for early and transparent system of disposal.

\section{Conclusion}

India is all set to utilize the disruption caused by COVID19 to lead a phase of rapid industrialization. Country's mining sector is the key to recover in the post COVID19. The suggested improvement in the grant of mineral concessions and better coordination between government agencies are few steps can be taken in this direction. The reforms initiated by the Government are aimed to impact the sector which is considered new horizons of growth, with the aim to unleash new investment, boost production and create jobs. During these challenging times, it is essential that the mine owners and operators take steps to

\begin{tabular}{|c|c|c|c|c|}
\hline $\begin{array}{l}\text { Sr. } \\
\text { no. }\end{array}$ & State & $\begin{array}{l}\text { Permission given by state government } \\
\text { to sale mineral at } 25 \% \text { of previous year production } \\
\text { (quantity) }\end{array}$ & $\begin{array}{l}\text { Iron ore sold by } \\
\text { SAIL }\end{array}$ & Remarks \\
\hline \multirow[t]{2}{*}{1} & Odisha & $2019-2020-2.3975$ Million tonnes & 0.155 million tonnes & \\
\hline & & $2020-2021-2.635$ million tonnes & 1.33 million tonnes & Sale up to December 18,2020 \\
\hline 2 & Chhattisgarh & $2020-2021-1.7$ million tonnes & 0.25 million tonnes & Sale up to December 31,2020 \\
\hline 3. & Jharkhand & $2019-2020-1.02$ million tonnes & NIL & $\begin{array}{l}\text { Permission not given by the state } \\
\text { government }\end{array}$ \\
\hline
\end{tabular}


carefully analyse and effectively navigate the challenges and propel the mining industry towards a new drawn. Mining in India may take to make India the $\$ 5$ trillion economy by 2024 as per Government of India 2020 2021 budget and help on speedy recovery from the economic impact of lockdown. Despite challenges posed by COVID-19, the country has to go on the industrial front and make India an Atmanirbhar Bharat or self-reliant India.
Supplementary Information The online version contains supplementary material available at https://doi.org/10.1007/s13563-021-00263-6.

\section{Declarations}

Disclaimer The views expressed in the paper are the personal opinion of the author. The Indian Bureau of Mines, the organization where the author works, does not endorse the view as expressed by the author nor does it assure any responsibility or liability for the same

Publisher's note Springer Nature remains neutral with regard to jurisdictional claims in published maps and institutional affiliations. 